\title{
Roundtable: How has the profession changed since you graduated?
}

\author{
Gerald Beasley \\ Holly Hendrigan \\ M.J. D'Elia \\ Compiled by Jessica Lange
}

Welcome to the second edition of Roundtable! Roundtable provides an opportunity for librarians to reflect on their own practice and experiences related to a particular question. In light of our 10th anniversary issue, the topic for this issue's Roundtable is "How has the profession changed since you graduated?" I'm delighted to have three librarians with a variety of experience sharing their thoughts on this topic. Enjoy!

\section{Gerald Beasley}

Vice-Provost (Learning Services) and Chief Librarian, University of Alberta

I believe the library profession has changed as much or more than I have since I graduated from University College London in the UK in 1985. I was fortunate to have excellent instructors in a School of Library, Archives and Information Science who emphasized attitude more than aptitude (although learning the principles of Universal Decimal Classification made every classification scheme I subsequently encountered look easy!). Computer science was an option—-thank goodness I took it-and my submission of a small but exemplary card catalogue now seems embarrassing. Still, I believe I carry the values that were reinforced at library school into my current work, especially by recognizing that librarianship continues to be about sustaining and developing communities through intelligent access to organized knowledge.

Having entered academia after many years of working in professional and special libraries, I wish I had not seen barriers arise between the various career paths. I now think I was just lucky. In general, the reward systems for public and special library work do not seem to have kept pace with the compensation and benefits offered to academic librarians, yet I believe the work remains comparable at all levels. Disappointingly, our failure to communicate our professional value has meant library work in nearly all sectors has become more precarious.

And I am dismayed that school libraries are under threat everywhere I look, and that volunteers are expected to replace trained professionals in many local libraries in the UK. On the positive side, however, I also believe the world has learned a lot from our profession. We are surely the unsung leaders in thinking deeply about the worldwide web, intellectual freedom, open access, and knowledge as the engine for economic and personal growth. The more that commercial interests shape the societies we live in, the 
more our professional expertise will be valued by those seeking a safe and informed environment for exploration and learning. Plus ça change, plus c'est la même chose!

\title{
Holly Hendrigan
}

\author{
Liaison Librarian, Applied Sciences; PI, TechBC Memory Project, Fraser Library, SFU \\ Surrey
}

Douglas Coupland has remarked, in numerous formats, "I MISS MY PRE-INTERNET BRAIN." Occasionally, I MISS MY PRE-INTERNET LIBRARY. At the very least, I feel privileged to have worked in one.

I graduated from UBC's library school in 1993, and had the great fortune of securing an auxiliary position in the busy Central branch of the Vancouver Public Library shortly thereafter. These were the final years of a predominantly print-based information marketplace. Granted, VPL's catalogue was automated, and subject divisions held a few databases on CD-ROM, but the pre-internet days were a golden age in which librarians were called upon to provide answers to both in-depth and ready reference questions from the moment we opened every morning. In order to answer them, we relied heavily on reference books and maintained our own index card and newspaper clipping files.

The index card drawer banks in subject divisions were magnificent. Sub-organized by subject or format, these physical databases contained citations or complete information on a wide range of topics: artists, authors, quotations, "quick reference" facts and statistics, boat plans, recipes. Some enterprising librarian even created a "Collective Noun" file, saving future librarians time when asked for the group term for, say, owls ("parliament") or monkeys ("tribe"). New librarians could work in every subject division thanks to the diligent use of LCSH on every card. Flipping through the heavy red volumes was an efficient way to point ourselves in the right direction when venturing into unfamiliar topics. To this day, I feel anxiety in unfamiliar databases until I find the controlled vocabulary.

How reference has changed. In the early 1990s, the Language and Literature Division frequently received a telephone call or a visit from somebody seeking to flesh out the following fragment of a poem: "I have slipped the surly bonds of earth." The phrase echoed in their minds, but they had no idea where they could find the full text. Today, you can Google several keywords and discover, in less than a minute, that the poem's title is "High Flight" and the poet is John Gillespie Magee, Jr. Not possible pre-internet; naturally, the Literature division had an index card for this poem in our Quotations card file. I'd recite the poem over the phone, because the electronic means of transmission at the time was the fax machine. (OK, I don't miss the fax machine!) While the question was routine, we still warmly received the gratitude of patrons who had been searching in vain for that poem. What a dream job for a Literature graduate.

While I don't think it's a bad thing that people can now find "High Flight" in an unmediated search, I do feel regret that a single corporation's interface has largely 
supplanted the role that libraries used to play in providing quick information. No librarian ever sold user data from their reference questions to a third party. It was unthinkable that searches in Consumer Reports would result in an appliance dealer trying to sell a patron a dishwasher.

Let us remember that Google is not providing its services for free. And we all know, contrary to popular belief, that not everything is "on the internet"; I am especially worried about the deliberate disappearance of Canadian government documents and the cuts to our national library and archives. It's become our responsibility to publicly remember and advocate for both the information and privacy rights that citizens once enjoyed... while they kept us front-line librarians so busy.

The pre-internet library, like Coupland's pre-internet brain, is a thing of the past. Reference librarianship in public libraries in the early 1990s was intense, meaningful work. Roughly five years into my career, Google's algorithm of relevancy-ranked results changed everything. Reference desks-and reference librarians, for that matter-are increasingly difficult to find in today's libraries. While I am fully engaged in the complex and variable duties of a contemporary academic librarian, I can't help but feel the occasional wave of nostalgia for the "Golden Age of Reference" I experienced early in my career. I feel enormously grateful to have caught the tail end of it.

\section{M.J. D'Elia}

Head, Learning \& Curriculum Support, McLaughlin Library, University of Guelph

I have a lot of thoughts about the changes I've seen in my career so far, but I'll keep it to four observations: 1) Finding is dead; 2) Engagement is essential; 3) Impact is our message; and 4) The future requires a new mindset.

Libraries aren't about finding information anymore. With a browser or a smartphone, everyone can do finding. People need libraries for what happens after the finding. They need help with the understanding, the evaluating, the choosing, the organizing, the synthesizing, the re-finding, the disseminating, and the list goes on. Libraries help more with the messy bits of sense making - and we're better for it.

Libraries are more intentional about engaging user communities. At the beginning of my career we talked a lot about service excellence (e.g. thorough reference interviews, pedagogically-sound instruction sessions, etc.). Service excellence is still important, but now we spend more time engaging our users, attempting to understand their behaviour and their motivations. We apply user experience techniques, adopt iterative design principles, and work in intensive sprints like start-ups. This outside in, patron-first approach leads to a deeper understanding of our users-and opens up exciting new opportunities.

Libraries are measuring impact differently. We have traditionally relied on brute quantitative metrics (e.g. library expenditures, presentations to groups, total visits, etc.), but those numbers tell an incomplete story. Now we are digging deeper into our data to 
understand how our programs, services, and collections propel our users forward. We're collecting and sharing richer stories of our contributions to campus-and there is a lot to celebrate.

In the past few years I've heard a lot of talk about making libraries "future ready." From my perspective, the future isn't about trendy job descriptions, or specialized skills, or more credentials on your wall. The future requires a new mindset. It's about being comfortable with ambiguity and uncertainty. It's about figuring stuff out when there is no formula. It's about risk, reward, and resilience. In short: the future is not something that happens to us; it's something that we need to build—so let's have some fun while we're at it! 